\title{
'MY PLUNDERED TOWNES, MY HOUSES DEVASTATION': THE CIVIL WAR AND NORTH MIDLANDS LIFE, $1642-1646$
}

\author{
By MARTYN BENNETT \\ Nottingham Trent University
}

This article will examine the effects on life in the north midlands during the first civil war, 1642 - 1646, and relate these to the absence of clubmen risings in the region. In recent years historians have offered various explanations for the risings of the neutralist clubmen in the south west and south and west midlands during $1645 .^{2}$ The most recent of these goes farther and attempts to explain why there were no such risings in other areas. Simon Osborne's 1994 article in Midland History, offers a multi-layered explanation for the risings in Worcestershire and for the lack of risings in neighbouring counties, Warwickshire, Northamptonshire and Leicestershire. His complex of explanations for the non-appearance of clubmen in the latter counties centres partly upon the ability of the local garrisons to maintain regular collections of taxation. This more orderly conduct was less likely to inflame local resentment which could build into anger. This argument also stresses the ability of these same garrisons to maintain order amongst themselves and overawe the local rural and urban populations. ${ }^{3}$ Part of this paper will examine Osborne's thesis in the light of the experience of the counties of Derbyshire, Leicestershire, Nottinghamshire, Rutland and Staffordshire, embracing one of the counties examined by Dr Osborne and four contingent to it. It is first necessary to present a brief narrative of the war to provide context, and then taking the counties in turn to highlight features identified by Dr Osborne. Finally the paper will turn to the question of the stability of the region in the second half of the war, the period which it might be judged would have created the right conditions for clubmen risings.

The civil war in the north midlands has had to be re-assessed recently. For a considerable period it was seen as a region dominated by a collection of what were termed 'rob-carriers', referring to the supposed predilection of royalist commanders for robbing carriers, or 'former tinkers', a reference to royalist claims that Parliament's commanders were of lowly origins. As a result there has been little attempt to examine the structures of the rival organisations or to re-examine the historical narrative. Partly this is caused by the nature of the source materials. Many royalist papers were destroyed 
at the end of the war, resulting in a skewing of the picture. The material at the centre of this paper, derived as it is from the local communities, has allowed for the picture to be redeveloped from the bottom upwards. ${ }^{4}$ Essentially for the north midlands, the story has a four-fold aspect. In the wake of the king's departure from Nottingham, the impetus lay with the parliamentarians who had been in hiding whilst the royalists were in the ascendant. By December 1642 these parliamentarians had control of Derby and Nottingham, and the only royalist force in the field, Sir Francis Whortley's dragoons, had been driven out and the only garrison, the amateur soldiers at Bretby in south Derbyshire had been forced to surrender the house. The king responded by sending back the region's active royalists to their homes from the field army at Oxford to retake the initiative. The second stage of the war was a battle for supremacy, in which the royalists had gained the upper hand overall by the following summer. However, they had failed to completely suppress the parliamentarians who most importantly held onto the county towns in four of the counties, something which was to have dire consequences for the royalists in the following year. The defeat of the royalist army at Marston Moor in 1644 heralded the next stage which saw the destruction of much of the royalist hold on the midlands, both by outside forces and by indigenous parliamentarians. This process accelerated after Naseby, becoming the final stage in which the royalists were pinned into the immediate vicinities of their major garrisons, a state of affairs which existed until the royalists were wheedled out of their strongholds one by one.

Much of the evidence for the realities of the midlands situation comes from the accounts of local constables with whom the administrations worked. As with much local government, central policy stood or fell upon the effectiveness of the constables and the consensus reached between him (or her) and the local communities. From their papers we know a good deal about the methods of collecting war-time taxes. Some 28 sets of accounts covering the north midland counties survive. This number does not represent a large proportion of the parishes in the region but compared with the rest of England and especially Wales, it is a relatively rich haul representing about half of the surviving sets for the two nations. Many sets had not seen the war out. The constable of Rugeley in Staffordshire had watched his house burn down, taking with it the accounts for $1643-4 .^{5}$ Others were simply not preserved; the constable at Edwinstowe in Nottinghamshire wrote in 1647 in a space left in the accounts:

'whereas ther wear manye maightye accompts in the years 1642,16431644 betwixt the townsmen of Edwinstowe and Myles Ouldham the then constable of the same towne w[hi]ch by reason of time of the warr could not nether then nor this daye be $\mathrm{p}$ [er]fected ${ }^{6}$

Even so, the surviving sets offer enough information to reconstruct the systems employed by the commissioners of array and the soldiers in their counties.

In Staffordshire the return of the local royalists and the immediate attempt of local parliamentarians to defeat them, ended the county's bid for neutralism. In November 1642 a special sessions of the peace had ordered the creation of a 'third force' to expel forces of both sides which might attempt to enter 
the county. Instead, by the end of the year people in the county were steadily drawn into the funding networks. Petty constables had visited the 'commissioners' at Lichfield as early as 29 November 1642 within days of the Justices of the Peace's attempt to declare neutrality. They were again called to Stafford by sheriff Comberford in February and by May a provisional levy of $£ 2000$ pounds had been imposed, and collectors appointed for each of the hundreds. The proportions of tax allotted to each division and then to each parish seems to have been related to the proportions used in the levies of ship money, the most recent all-embracing county wide tax. One of the best sets of accounts in the country is the one from Mavesyn Ridware in Offloe Hundred, Staffordshire. ${ }^{7}$ Here the accounts reveal the process of allotment and collection. Constables in office between 1643 and 1645 each travelled fortnightly to Lichfield to hand over contribution to the treasurer and former cathedral chorister, captain Jeffrey Glasier of Richard Bagot's Foot. Evidence from elsewhere in the county supports this, in Seisdon Hundred constables were expected to travel to their respective garrison, in this case Dudley. ${ }^{8}$ The costs to the communities of the royalist tax known as Contribution were high and they escalated. The Mavesyn Ridware accounts show the yearly contribution totals for 1642-3, 1643-4 and 1644-5. In the first year (which runs for the period October to October), the total paid was $£ 30$ 13s 7d. By 1643-4 this had risen to $£ 14417 \mathrm{~s} 4 \mathrm{~d}$, but in $1644-5$ the total had fallen slightly to $£ 128$ $13 \mathrm{~s} 3 \mathrm{~d}$. However the total village outlay was even higher, for during the latter two years there were periods when money was also paid over to the parliamentarians at Stafford. In 1643-4 payments of Parliament's Weekly Assessment had only amounted to $£ 475 \mathrm{~s} 0 \mathrm{~d}$ but the year following it rose to $£ 87$ $7 \mathrm{~s} 9 \mathrm{~d}$ accounting for the smaller payments to royalist coffers that year. It is difficult to compare these amounts with the pre-war levies, but a few such comparisons from Staffordshire can be drawn. At Biddulph levies in 1640 amounted to $£ 89 \mathrm{~s} 7 \mathrm{~d}$, whilst in 1645 they had risen to $£ 2612 \mathrm{~s} 6 \mathrm{~d}$, approximately a three-fold rise. ${ }^{9}$ In Rugeley, surviving accounts not burnt in Robert Burton's house show pre-war levies at around $£ 17$, whilst those for 1644-5 had reached $£ 4313 \mathrm{~s} 4 \mathrm{~d}$, again approaching a three-fold increase. The income of garrisons too naturally increased, with Lichfield drawing some $£ 48$ per month from Offloe Hundred in 1643 and something like $£ 100$ per month in late $1645 .{ }^{10}$

In Nottinghamshire the best set of accounts come from Upton near Newark. ${ }^{11}$ The other accounts in the county play an important supporting role and all demonstrate clearly that the posturing of the two sides in the summer of 1642 introduced expensive burdens to the villages. In late August that year the trained bands were summoned to Nottingham at short notice for the 'Raising of the Standard'. To get them from the Newark area quickly required horses and at Upton three were hired at a cost of 3s 3d. The soldiers' wages cost $16 \mathrm{~s}$, the constable had to accompany them which cost the village $6 \mathrm{~d}$ in expenses and $2 \mathrm{~d}$ in horse hire. The village armour was in a poor state and needed $2 \mathrm{~s} 6 \mathrm{~d}$ worth of repairs and another shilling was spent on gunpowder and match. Finally a month's pay, 10 s $6 \mathrm{~d}$, was handed over to the high constable bringing the total to $£ 113 \mathrm{~s} 11 \mathrm{~d}$. Nearby Coddington too had to find 
horses for its trained bandsman and a boy to help the constable to bring the horses back again with wages, powder and match the bill there came to 10 s 6d. ${ }^{12}$ Despite the hurried activity it is not certain that these soldiers arrived before the standard was raised, possibly they did not, accounting for the poor military turnout at Nottingham on 23 August 1642.

During the next few months the region was on the periphery of the war, but not isolated from it. The number of travellers along Upton's roads was already being swollen by refugees from the rebellion in Ireland. From the beginning of 1642 , refugees streamed through the midlands. During the year 94 men, women and children from Ireland passed through Upton, some of them were maimed soldiers, one woman colonist had been born in Southwell. There were other travellers too: maimed soldiers from the king's army, wounded in the early battles began to pass through in late October or early November, seven had travelled through Upton before the end of the year. Coddington saw some 78 refugees pass through between March 1642 and the following January including five soldiers maimed in the autumn fighting. Probably some of them were people who had already passed through Upton or were about to do so. Some travellers believed that succour lay with the king and a constant trail of them followed him to York or Lincoln.

The burden placed by the unfolding war upon Nottinghamshire villages increased dramatically over the next few years. By February 1643 the Coddington constables were making trips to the commissioners at Newark for the first recorded monthly meeting. ${ }^{13}$ Thorpe constables were also at the meetings, and copies of warrants were brought by Edward Milden at $4 \mathrm{~d}$ each to take home to show his neighbours, the social equals who would share the village's administrative posts and duties with him. ${ }^{14}$ For Thorpe these warrants represented the beginning of regular royalist taxation which was set at $£ 110$ s od a week for the next year. Commissioners of array, through the high and petty constables were soon able to collect taxation from most of the county, including places as near to the parliamentarian garrison at Nottingham as Arnold to the north-east and Clifton to the south. The exceptions were the villages to the south and west of Nottingham, from where only the parliamentarians could gather tax most of the time, because royalist forces could not usually cross Trent Bridge. ${ }^{15}$ At Upton the total receipts of the 1645 levies brought in a total of $£ 1330$ s $5 \mathrm{~d}$ and the high level of taxes and the continuing ancillary costs resulted in the 1646 total disbursements remaining at $£ 140$ 8s od.

The accounts from Upton also reveal how the demands of war reached deep into the workings of the rural community. We know what was produced, who produced it and who consumed it. In Upton dairy products were provided chiefly by George Bilbie. Arable crops grown in Upton included peas, provided by John Lambe, George Bilby, Rowland Robinson, William Parlethorpe, Richard Aseling, John Chappell, William Kitchen and William Gill. Wheat was grown by George Bilby, rye by William Robinson, and oats by Salomen Bettinson and Rowland Robinson. There was a variety of livestock reared in the village, sheep were kept by Daniel Koe, William Kitchen, and George Parlethorpe, whilst pigs were kept by the wives of William Gill and Richard 


\section{Garrison towns and villages mentioned in the text}

^ Royalist garrisons $\square$ Parliamentarian garrisons
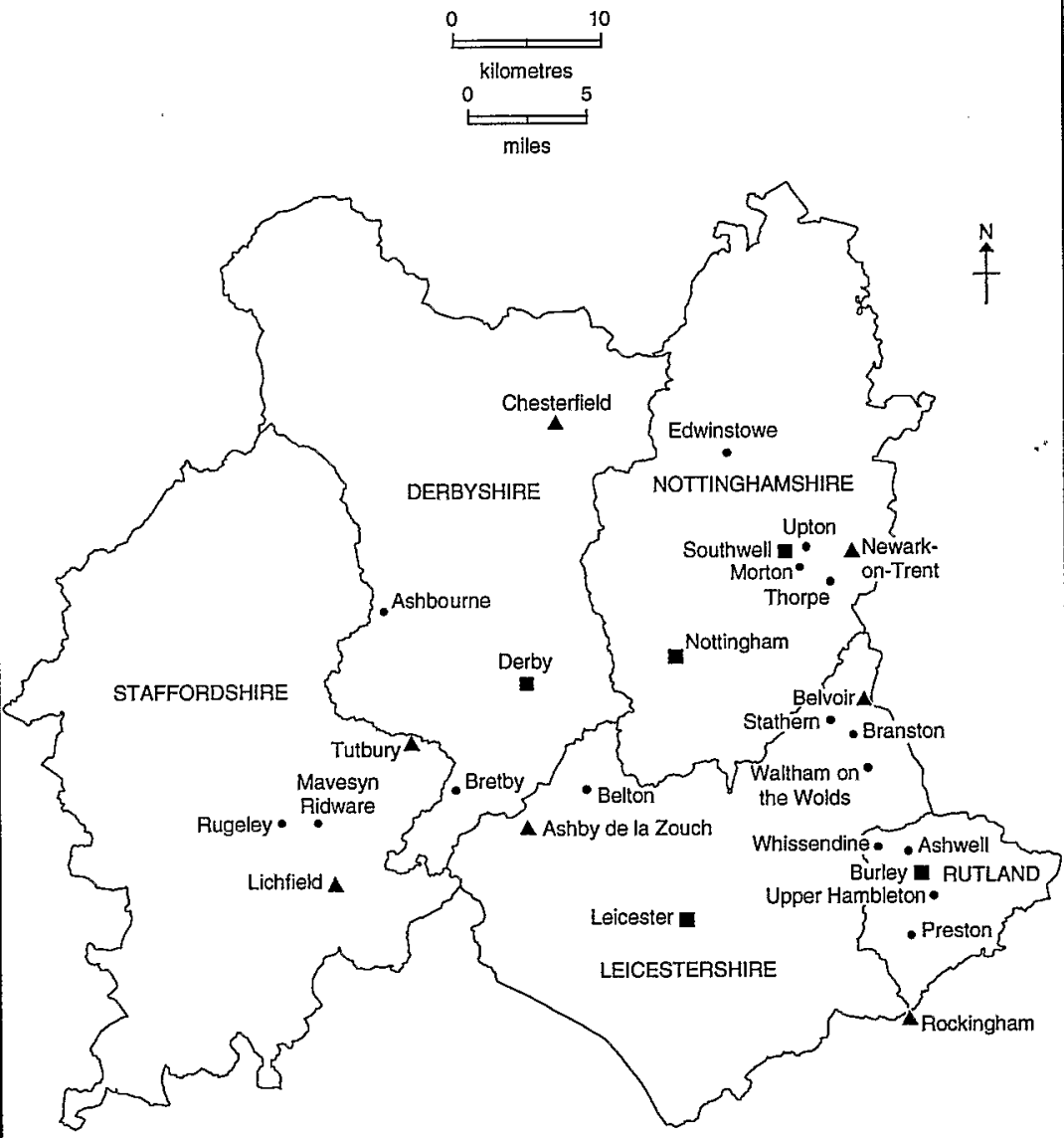

Figure 1. 
Skinner. Ducks could be provided by Robert Parnell's wife and chickens by Thomas Bayley. Produced goods are also in evidence: linen ware was made by several women including 'Kirke's wife', 'Thomas Kitchen's wife' and 'Stephen Shepherd's wife'. Bread was baked by Thomas Culling in 1645. Service industries were apparent too, ale and board was available at the Kirkes' inn, but ale was provided by others, including the Skinners, the Plowmans and the Parnells, and constable Jane Kitchen owned brewing equipment. Edward Harper and William Foster undertook metal work, with at least the latter shoeing horses for the army.$^{16}$ Other services were also required: reading warrants was sometimes undertaken by $\mathrm{Mr}$ Oglethorpe when the constable was away or not literate, and George Elliot often acted as a scrivener, copying warrants and writing up the accounts. All of these goods have been recorded only because the war efforts was drawing them from the Nottinghamshire rural economy.

The villagers with the larger houses were those chosen to billet soldiers allocated to Upton. Evidence from other accounts elsewhere demonstrates that the constables periodically drew up lists of the substantial householders for this purpose. At Upton we find the people most often referred to as innholders were selected for this duty. The Kirkes's inn usually had soldiers loding or convalescing there; Thomas Kitchen's household at Lane Head was another which provided lodging for soldiers and stabling for horses, and more soldiers lodged with John Kitchen. In 1644 George Bilby and William Gill jointly quartered four gentlemen, possibly officers or involved in the administration of the war. No precise figures for billeting costs are found in these accounts, but it is probable that they were in the region of $4 \mathrm{~d}$ per day for one man or one horse. ${ }^{17}$

The resources of this county were divided three ways for most of the war and variations within that pattern characterise the entire war. In the immediate vicinity of Leicester, the parliamentarian county committee was able to collect assessments most of the time although at the end of 1643 they were having to be subsidised by money collected in Kent. At the same time committee members themselves were allegedly not able to collect rents from their estates outside the town walls. The county as a whole was divided between the two royalist garrisons at Belvoir Castle and Ashby de la Zouch; the lion's share going to the massive garrison and administrative centre established at Ashby.

Principal accounts in Leicestershire, include Branston, Stathern and Waltham on the Wolds, all belonging to Framland and East Goscote hundreds assigned to Belvoir. The lone set from within Ashby's territory, the accounts from Belton demonstrate that the increasing burden on the village communities even in the early stages of the war involved a threefold increase on the constables' levy alone. ${ }^{18}$ The Waltham Accounts show that even in 1645 the Belvoir garrison could collect contribution on a regular basis, levying $£ 99$ 16s $4 \mathrm{~d}$ from the village that year. The accounts of nearby Branston that same year exhibit the dilemma of divided territorial control recording $£ 50$ paid to Belvoir and $£ 90$ to the parliamentarians at Leicester. Moreover, both the Waltham on the Wolds and the Branston accounts suggest that regular payments had been made to both sides for much of the war. Only during the period from autumn 
1643 to summer 1645 were the royalists in complete control. ${ }^{19}$

Considerably less can be said of Derbyshire and Rutland. In Derbyshire the commission of array structure seems to have been quite sophisticated, employing a system of devolved government. Part of the commission was based at Ashbourne to deal with the adjacent High Peak area. Most of the commissioners probably remained at Tutbury, although it is possible that there was also a contingent in the Chesterfield area. Chesterfield was the scene of the Marquis of Newcastle's Councils of War in late 1643, and the area was home to two of the commissioners of array. There are no surviving constables accounts which cover the early part of the war and so the taxation details remain largely a mystery, even though the division of the county between the garrisons can be worked out. It would seem that county borders did not dictate divisions between garrison territory whereas hundredal or warpentakal ones did. For instance tax was collected in Derbyshire by the Tutbury garrison in Staffordshire. In this case the taxes were probably being levied in the Honour of Tutbury the areas in both counties charged with the upkeep of the castle. However no such traditional arrangement would present a precedent for the allocation of Repton and Gresley hundred to the Leicestershire garrison at Ashby de la Zouch.

In Rutland the taxation process only becomes clear after the county was in the hands of the parliamentarians from 1644. The village of Preston paid tax to the county committee at Burley House for much of the time, but on some occasions had to make payments to the committee of neighbouring Leicestershire. ${ }^{20}$ At Hambleton, about three miles away, it was the Burley and Rockingham garrisons which drew upon the resources of Abel Barker's estates. Between 16 December 1644 and late June 1645, Barker despatched $£ 190$ s $9 \mathrm{~d}$ worth of peas, oats, straw, beer and 'provision' to 'Burley' at weekly intervals. He also provided five horses, which he valued at $£ 40$ to Rockingham. ${ }^{21}$ In 1645 the Monthly Tax levied on the county's five hundreds amounted to $£ 51010$ s $0 \mathrm{~d}$, with the village of Hambleton paying some $£ 1610$ s $0 \mathrm{~d}$ a month, only Whissendine, Ashwell and Burley paying more. ${ }^{22}$

The weight of evidence for the period before late summer 1644 points to the type of stability which Osborne rightly suggests would obviate the financial impetus for risings. Taxation collection was regular well into 1644 in many of the villages in the region. Even in this period there were areas where such stability did not exist, parts of Staffordshire adjacent to the garrisons of Lapley in the south west and Eccleshall in the north changed hands with the vicissitudes of war. The former changed hands twice in quick succession and the former once in the second half of 1643. The situation in Derbyshire in the same period was far more confused than that in other counties because of the rapid establishment of royalist garrisons. Moreover all the villages in the immediate vicinity of all the county towns were faced with royalist incursions throughout the war.

If the first part of the war was generally stable, the campaign in the Newark area in March 1644 heralded a sea-change. At the beginning of the month Sir John Meldrum and an army of 7,000 placed the royalist garrison at Newark under close siege. The resources of the area around the town were stretched 
during the next three weeks. Meldrum's defeat by Prince Rupert and Lord Loughborough was followed by billeting of royalist regiments from Loughborough's North Midland Army which took peas and oats to feed their horses and tried to take new mounts from Upton. ${ }^{23}$ The Upton Accounts clearly show a new phase in the war when resources were used more. Within ten days of the siege, the village was contributing labourers to the rebuilding and expansion of Newark's defences. Thorpe village accounts show that the villages were charged with the construction of certain amount of earthworks, assessed in ten-yard stretches. ${ }^{24} \mathrm{We}$ can get some idea of the costs involved from the Upton accounts, labourers were escorted to the bulwarks by the constable and they did a day's work for 8d each, which compares with 8d for a day's work mowing hay in Lincolnshire in 1621 , or between $6 \mathrm{~d}$ and $10 \mathrm{~d}$ a day as a foot soldier. ${ }^{25}$ However, events further north were to have a major effect on the north midland counties. On 11 April the Yorkshire royalists, charged with defending the Marquis of Newcastle's rear whilst he tried to halt the advance of the Scottish Covenanter Army into the north of England, were defeated at Selby. Suddenly the whole of the royalist north was under threat and York itself in peril. The Marquis dashed south, flung himself and his foot regiments into York and sent the horse south to camp in Nottinghamshire. That this drained the stocks of fodder in the midlands is apparent in the Upton accounts where the entries from the end of April, through May are dominated by the demands of horse regiments for peas, hay and oats as well as for new billeting arrangements. ${ }^{26}$ The effects of having Goring's horse in the region were felt in Derbyshire too. Colonel John Freschville wrote to Lord Loughborough in May 1644 complaining that Goring was expecting a 'greater quantity' from the county than 'the place can possibly afford'. ${ }^{27}$

Back at Upton Meldrum's three-week stay had also heralded another new feature, the payment of taxes to Nottingham, and despite the royalists' renewed hegenomy of the region or the constables' subsequent attempt to delete the sums from the accounts, parliamentarian taxation was not to end even for communities so close to royalist garrisons. By September such chaos had increased on the Derbyshire and Staffordshire border, with Sir Andrew Kniveton, governor of Tutbury writing:

...our contribution being much lessened by reason of the country's poverty and the enemy appearing daily in our quarters, and having no better a means of supply than by sending to particular men for some small sums such as they are well able to bear...

Here though there were still acknowledged hierarchies within the collapsing war effort. Kniveton continued:

...I make bold to aquaint you herewith and to present a copy of one of the notes (I intend to send) to your view, with a desire that you will please to approve of this or such other form as your lordship pleases and return it back this night, the occasion being urgent. ${ }^{28}$

In other areas these hierarchies were being challenged and the royalist war effort was becoming internally riven. In north-east Leicestershire the governor of Belvoir Castle ceased to recognise the authority of his commander Lord 
Loughborough. Since the summer of 1644 and the flight of the Marquis of Newcastle, Gervase Lucas argued Loughborough's commission was null and void, as he had been at one stage Newcastle's appointee. Lucas stopped attending councils of war, refused to help Loughborough's attempt to rescue the garrison at Wingfield, and challenged his commander's right to allot taxation areas. Lucas's men were collecting money from all of Framland hundred, which was shared between the two garrisons, and from East Goscote and Gartree which had been assigned to Ashby alone. Moreover, Loughborough also accused Lucas of badly treating royalist supporters, persecuting a Mr Yates whose two sons had been killed in the king's service. Such actions could not win hearts and minds and belie some degree of panic. The recipients of Kniveton's loan letters may too have felt betrayed by those supposedly protecting them from arbitrary demands. Lucas's action was not solely inspired by rivalry with Lord Loughborough, nor was it entirely as Loughborough asserted, corruption. Belvoir's financial situation was becoming desperate. Lincolnshire, where a good deal of Lucas's taxation had come from was now in the hands of the Eastern Association forces and administration. ${ }^{29}$

Similar disputes to the Lucas/Loughborough quarrel beset Staffordshire where Thomas Leveson governor of Dudley accused the Lichfield garrison of forcibly interfering in Dudley's tax collection. The dispute dragged on into the following year when Leveson went on to allege that the county's commissioners of array were not authorising the collection of monies due to his garrison. ${ }^{30}$ These quarrels were not helped by the confusion of commands at the level immediately above Lord Loughborough. Four of his five counties had been under the command of the Marquis of Newcastle, which had itself dissolved when the Marquis left the country; the fifth, Staffordshire, had been grouped under Rupert's command since Spring 1644 . This not only allowed Lucas could claim that Loughborough lacked authority, but also allowed Leveson to appeal over his head to Prince Rupert in 1644 and in 1645 to Prince Maurice.

The decline in royalist effectiveness was not yet clear to all observers. A petition sent to Parliament from Leicestershire in late 1644, protested the ineffectiveness of the county committee in dealing with the royalists. It claimed that:

...the enemy's are so much strengthened and increased, that the well-affected are daily exposed to the loss of liberty, their goods to plunder, and their rents sequestered and seized on by the adverse party, that till of late had never the boldnes or power to attempt it.

This claim that the people of Leicestershire were now subject to the 'now unbounded enemy' does not sit well with either our understanding of the situation in late 1643 when the royalists were ascendent, or late 1644 when they plainly were not. ${ }^{31}$ This petition's claims on this point only really make sense if we put them into a context of collapsing war-effort when sporadic tax collection had replaced effective systems. It was a period in which Abel Barker a member of the Rutland County Committee could question the value of the cause when it could not protect him or his property and a fellow countyman Francis Wayte claimed 'that the parliamentarian cause did not 
preserve his house from plunder or stop 'myself [being] carried away as most of our gentry already are'. ${ }^{32}$

There is other evidence that the breakdown in the royalist control of the region was having widespread effects. At Upton just after 3 July 1645, William Robinson was murdered by soldiers from Newark. Constable William Cullen arrested the soldiers and led them to Newark. On 10 July, he, Robinson's wife and other witnesses went to give evidence before the Council of War. By that time there were parliamentarian soldiers in the area, some based at nearby Norwell..$^{33}$ Taxes were being paid to both Newark and Nottingham but the collections were less regular. Parliamentarian journals even suggested that the Newark forces were threatening to burn down empty houses, on the basis that their owners had fled rather than pay taxes, whilst they were collecting arrears. Whilst there is no corroboration for this claim, there is no doubt that royalist systems were breaking down and new parliamentarian ones were not yet established to take over from them. ${ }^{34}$ Evidence from the extensive estates of the Mellish family, covering several villages in the north east of Nottinghamshire indicate that the dysfunction engendered by the breakdown of control was also affecting rents collection. On the eve of war total rents collected ranged between $£ 628-£ 690$ per year. For $1642-3$ they remained high at $£ 650$ $14 \mathrm{~s} 1 \mathrm{~d}$, and the following year they were still at $£ 652 \mathrm{ss} 1 \mathrm{~d}$; they remained the same into $1644-5$ but by 1645-6 they had fallen to $£ 4104 \mathrm{~s} 9 \mathrm{~d}$ (a $37 \%$ fall). ${ }^{35}$ This in part must be because the Mellish estates were on the fringes of territory which the Newark based royalists could control by 1645 . The cumulative effects of the levies upon the tenants' ability to pay their rents would also be a factor.

It is possible that for many places such disorderly behaviour was a brief occurrence with limited effects. Elsewhere in the region, where control passed swiftly into the hands of the parliamentarian forces and administration, the changeover could be marked not by instability, but by a sense of déjà $v u$ as parliamentarian levies were set at almost exactly the same rates as royalist ones. The Mavesyn Ridware accounts show that in some areas where there was a prolonged period of dual assessment, both sides made an effort to reduce the possible problems by lowering their levies by approximately one third. As part of the surrender terms at Welbeck in Autumn 1645, the parliamentarians, under Thomas Gell, agreed to collect royalist contribution representing the back pay of the besieged garrison.

For the people of the area surrounding Newark the cost of the war escalated at the end of 1645 when the town was again besieged by Lord Leven's Covenanter army and Sydenham Pointz's Northern Association Army. This siege lasted some six months but even when it ended in May 1646, the departure of first the Scots, then the royalists and finally the northern parliamentarians did not significantly reduce the costs of war. One mark of how little was to change is the way that 6 May, the day the siege ended, was passed by the constable of Upton in collecting parliamentarian taxes in Morton. Whilst the Scots' levy may have ended that very day, he now had to hand over all the money to the parliamentarian county committee in Nottingham and two week's money, representing the period since the siege, was paid over 
on 26 May. Newark was now afflicted by plague and occupied by John Hutchinson's regiment from Nottingham. His wife recorded this as the 'greatest danger of all' he underwent and recounted with relief, that 'it so pleased God that neither he nor any of these fresh men caught the infection, which was so raging there that it almost desolated the place ${ }^{36}$

This would seem to suggest that the infection was closely related to the unhygienic living and diet of the straitened garrison and that the soldiers with fresh food and supplies were able to avoid infection at this stage. On Monday 11 May workers from the nearby villages were set to work to destroy the earthworks established by both sides. The labourers from Upton were given the task of demolishing the king's Scone on the Spittle which they themselves had constructed two years earlier. Many of the earthworks were levelled or at least rendered unserviceable within days. Work was quickly halted by the plague in Newark and the villages sealed themselves off from the outside world as much as possible. On 26 May, constable Richard Gibson at Upton gave $10 \mathrm{~d}$ worth of bread, cheese and beer to 'six people of Newark which the watchman kept out of the towne the[y] desiringe relief, returned to the wood'. ${ }^{37}$ The payments to support the people in the plague visited towns all around the country continue to appear in the Upton Accounts throughout much of the rest of 1646 .

Mass movement of people across the country had really begun in 1641 with the migration of refugees from Ireland, but now a great throng of people was moving along England's roads. The year from 6 May 1646, the first after the war ended in the vicinity of Upton, saw at least 58 Irish men, women and children pass through, along with three disabled people, nine soldiers returning home, at least nine children, six women and eleven men of various qualities, in all at least 96 people. Initially they may have used Upton's roads to avoid plague ridden Newark and many people would have been turned away from the town by watchmen there. Yet it is clear that the plague was only one reason for people passing through Upton and the surrounding villages as it cannot account for the continuing traffic of the displaced which continued for several years. Three years later, in 1649, the numbers on the road were even greater. This time sixteen Irish women, one Irish child and one Irish man passed through Upton. In addition there were sixteen women, seven men, seventeen disabled people, eight children, 24 discharged soldiers, eleven maimed soldiers, fifteen people of unspecified gender as well as a further six 'companies' of poor people and sixteen Irish 'companies' of unspecified numbers which passed through. Payments to these travellers cost the community over $£ 2$, or about $3 \%$ of total expenditure for that year or about $5 \%$ of the village payments other than those for the Monthly Tax and billeting charges. Despite Professor Wood's assertion that 'the normal trade of the countryside soon began to flow into the market place', Newark's role as a major communications route was seriously disrupted ${ }^{38}$ People now used other roads. Upton was passed through by people generally moving north to south or vice versa; York, London and Parliament were common destinations. It is interesting that there was so much traffic through Upton as the village was neither on the main roads north and south, nor on the direct route between Nottingham and Newark. For much 
of the war period and after it seems likely that people following the Great North Road were skirting around Newark to avoid the bridges and roads damaged by siegeworks and fortifications, perhaps by way of Long Bennington, Cottam, East Stoke, Fiskerton Ferry, Upton Norwell and Tuxford. ${ }^{39}$

In spite of the very great depredations and the overall uncertainty caused by the collapse of the royalist war effort, no club risings took place in the north midlands and this poses interesting questions. Dr Osbourne has addressed this issue in his recent work on the adjacent and overlapping parts of the midlands. His offered solution in part relates to the establishment of order in the regions. In those areas with the most effective military control, and thus the most regular system of taxation, order and stability were preserved, and there was no need of any expression of popular outrage. Garrisons in these areas were effective at minimising minor military incursions from outside. Taxation collection probably entailed almost constant patrols. Evidence from Colonel Staunton's regimental accounts suggests that responsibility for collection entailed long journies, often to distant communities. ${ }^{40}$ This could be fundamental to the preservation of order as the regular presence of armed forces collecting taxes, would have had an intimidatory effect or may have had the effect of enhancing a sense of security. In the north midlands there are two problems with Osbourne's solution. Firstly it fails to explain why the disorderly effect of marching armies passing through regions which had, as he acknowledges, been a problem in Worcestershire did not cause problems here. Indeed there had been many occasions when royalist and parliamentarian armies marched through and lingered in the region. In 1643 and 1644 the royalists armies of Newcastle, Prince Rupert and Lord Goring travelled through or even stayed for a considerable amount of time causing considerable hardship. ${ }^{41}$ In 1645 the king's own army was in the region three times between May and November. Parliamentarian armies, under firstly Thomas Ballard, then Cromwell, Grey and Meldrum had been in the region in 1643. Meldrum was in the region again in Spring 1644, the earl of Denbigh in the south during June, Manchester in August and in 1645 the New Model and the Scottish Army had all disrupted any sense of normality. We have seen from the Upton accounts and from the material regarding the period of Goring's stay in the region, that the burdens imposed by outside forces were erratic and potentially destructive. Secondly, the period which saw the clubmen activity at its most intense in the south midlands, the marches and the south west co-incided with the most destablised period in the north midlands. The defeat of the North Midlands Army at Denton in October 1644 had seen the end of its existence of a field army; from then onwards it was relegated to being garrison force contributing to other armies. Regiments under the argumentative colonels joined the king's army separately in May 1645 or as a part of another recognised body such as the Newark Horse. The North Midlands Army was still large enough to dominate significant areas around the major garrisons, and it certainly ensured that Parliament's forces could not hold the territory in the same thrall as Lord Loughborough's men had in the period Autumn 1643 to Spring 1644.

The region was not entirely quiet, but disturbances in the area were an urban 
rather than a rural feature. As in royalist Chester the previous year, parliamentarian Derby was beset by anti-tax riots. ${ }^{42}$ In May 1645, two unnamed women,

went up and down the town beating drums and making proclamations... that such of the town as were not willing to pay excise should join with them and they would beat the [excise] commissioners out of town.

Attempts by the county committee to negotiate with them failed and as the committee sat at the mayor's house, one of the women stood banging her drum outside the window drowning out the debate. This tactic worked and the excise was not collected again until July. When it was again levied a soldier was seized by the townspeople and fastened to the bull ring in the market whilst 'the women did beat the drums as before'. It still proved impossible to collect the money, despite orders from London. When the excise commissioners could do their work again the tax was this time used primarily within the county and not sent to London. Sir John Gell the governor of Derby partly for his own ends, probably persuaded Parliament that this was more acceptable to the rioters. ${ }^{43}$ If indeed this had been an aim of the rioters, as well as that of Gell, it fits in with some of the demands the club movement, and the gentry petitions which a few months earlier, pressured the king to keep locally collected taxes within the area for regional use. Royalist excise was collected in the region, and there is some limited evidence for its organisation and implementation. However, as it came into force just as the royalist cause went into decline in the north midlands, its effects seem not to have been prolonged enough to have provoked complaint.

We need other explanations for the absence of clubmen risings. Absence does seem to support Professor Hutton's assertion that the Club phenomena were individualist in their composition, demands and behaviour. That there were no risings in the midlands at a time when there were so many of the prerequisites found in areas marked by Club risings, would suggest that there were particular circumstances and sets of circumstances which did not occur within the midlands. The answer may lie between the two extremes of class conscious risings and individual self-expression. Risings elsewhere undoubtedly had several things in common. The clubmen and women in all cases were defending themselves and their communities against damaging outside forces. They were relating their own personal circumstances and those shared by their neighbours, to the general instability within the state represented by a breakdown in government. Risings were organised and led by those involved in the lower, community levels of local government, high and petty constables such as high constable Thomas Careless of Broxash, prominent in the Herefordshire club movement. They were also the people charged with administering the war efforts at community level. This suggests that the club risings are an example of a clash caused by there being two concepts of order even in war-time. The order of the constables and local communities being at variance with that of the central representatives of order - in this case royalist and parliamentarian authorities rather than traditional functionaries of government. In this circumstance the clubman constables and their neighbours 
represented order and the soldiers, commissioners and committeemen disorder. In the north midlands, whilst the centre tottered and changed its face, it certainly never fully collapsed or embraced unacceptable practices as it did elsewhere.

Absence of prominent roman catholic figures, removed one other area of contention. The Worcestershire Clubmen exhibited 'extraordinary venom' in their attacks on catholics. ${ }^{44}$ Hutton identifies the prominence of the earl of Shrewsbury, in the Marcher Association as a major cause of the Clubman activity there: powerful roman catholics were an unacceptable part of government. Although Henry Hastings, Lord Loughborough had been accused of favouring catholics in his forces, the accusations did not stick and whilst there were two roman catholic colonels in his army, the overall proportion in his officer corps remained low at as little as $15 \%$. There were no catholics in the administration. The one exception was Thomas Leveson at Dudley who was widely described as a 'rob-carrier', and who managed to persuade the king to make him high sheriff in 1645, but who was generally kept isolated by the commission of array, effectively localising opposition to his presence in the area. ${ }^{45}$ In fact, Leveson was perhaps the nearest thing the region got to the other spark for club activity, the militant swordsman who like Barnabas Scudamore at Hereford provoked armed local opposition to his heavy-handed policies. Leveson's isolation and the actions taken by the king and princes Rupert and Maurice to bring him into line prevented any escalated action against him.

This all seems to suggest that a combination of general factors and specific factors were necessary to prompt people into taking up arms against the protagonists. Whilst the general causes of the civil war, deprivation, uncertainty and heavy burdens, combined a decline in stability and confused control were to be found in the north midlands, particularly after Summer 1644, other more specific grievances were absent. In the north midlands circumstances surrounding the royalist defeat and determination by both sides to ameliorate the worst effects of the war mitigated these problems. For a significant amount of time the consensus between centre and locality obtained: roman catholics were rare, no colonel or governor was too arbitrary in his actions, and the needs of Lord Goring's forces were incorporated into an effective logistical framework and thus he did not engage in the kind of arbitrary taxation which was, later in the war, to provoke the people of the south west into rising.

\section{NOTES}

1 The title is taken from Anne Bradstreet's $\mathcal{A}$ Diologue between Old England and New, concerning their present troubles Anno 1642.

2 For those interested in exploring this theme, the principle works are: J.G. Lynch, 'The Risings of the Clubmen in the English Civil War' (Manchester University M.A. thesis, 1973); J. Morrill, The Revolt of the Provinces (London, 1976), 98-111; R. Hutton, The Royalist War Effort (London, 1981), 159-165 and 'The Worcestershire Clubmen in the Civil War' Midl. Hist. V (1979-80), 40 49; P. Gladwish, 'The Herefordshire Clubmen: A Reassessment' Midf. Hist. X (1985), 62-71.

3 S. Osborne, "The War, the People and the Absence of the Clubmen in the Midlands, 16421646', MidL. Hist. XIX (1994), 85-104. 
4 See M. Bennett, The Civil Wars of Britain and Ireland (Oxford, 1996), chapters 6 and 8 for the context, and 'The Royalists War Effort in the North Midlands 1642-1646' (Loughborough University, Ph.D. thesis 1986), chapters 2 and 4 for an analysis of the rival war efforts and chapters 5 and 6 for a complete narrative history.

5 Staffordshire County Record Office (hereafter, SRO), D1454/2, np. To get a value similar to today's prices, multiply the sums by 75 .

6 Nottinghamshire Archive Office (hereafter, NAO), PR2130, Edwinstone Constables Accounts, fo. 12 .

7 SRO, DE 3712/4/1, Mavesyn Ridware Parish Book.

8 R.S. Shaw, History and Antiquities of Staffordsfire (London, 1798-1803 repr. Ilkley, 1976), I, 60 .

9 SRO., D3539/2/1, Biddulph Parish Book, np.

${ }^{10}$ Lichfield Cathedral Library, Ms 24 The True and Perfect Account of the Expenses of Collonell Richard Bagott; Lichfield Joint Record Office, D30 LIIIB, Contributions to the Garrison in the Close.

$"$ NAO, PR1710, Upton Constables' Accounts: published as M. Bennett, (ed.), A אottingfiamsfite Village in War and Peace: The Accounts of the Constables of Uptom, (Nottingham, 1995).

${ }^{12}$ NAO, PR 1529 Coddington Constables' Accounts Levies np.

${ }^{13}$ NAO, PR1531 Coddington Constables' Accounts, 1641-1769, np.

14 NAO PR5767, Thorpe Constables' Accounts, np.

${ }^{15}$ M. Bennett, 'Royalist War Effort', ch.2 or 'Contribution and Assessment: Financial Exactions in the First Civil War, 1642-1646.' War and Society, IV (1985). They could cross Trent Bridge on the occasions in which they captured the fort there. The Toton rentals show that the Royalists could reach this area of the county on these occasions. NAO, D35/5.

${ }^{16}$ Bennett, (ed.), A Nottingfanthfire Village, xxiii-xxiv and 10-45 passim.

17 See for example the Lady Martha Button (or Dutton), NAO, DD 4P 55/49. This account actually refers to Devonshire. At Powick in Worcestershire Margaret Staunton was promised payment of 2s 10d a week for quartering one man, Public Record Office, SP 28/152, Accounts of the Constables of Powick, p.4.

${ }^{18}$ Leicestershire County Record Office (hereafter, LRO) DE1965/41 Belton Constables', Churchwardens' and Overseers' Accounts. np.

${ }^{19}$ LRO DE25/60 Waltham on the Wolds Constables' Accounts, fo.68; DE720/30, Branston Constables' Accounts, p.62.

${ }^{20}$ LRO, DE 2461/135, Preston Civil War Receipts.

${ }^{21}$ LRO, DE730/3, The Papers of Abel Barker, fols. 49 and 50.

22 Ibid., fo.52.

${ }^{23}$ NRO, PR1710, fo. 24.

24 NRO, PR 5767.

${ }^{25}$ Historical Manuscripts Commission, The Manuscripts of his Grace the Duke of RutLatd, Twelfth Report, Appendix Part IV, I, (London, 1888), 460-461; C. Carlton, Going to the Wars: The Experience of the Britisf Civil Wars, 1638-1653, (London, 1992), 94.

${ }^{26}$ NRO, PR1710, fols.24-7.

${ }^{27}$ Historical Manuscripts Commission, Report on the Manuscripts of the Late Reginald Rawdon Hastings, 4 Vols. (London, 1930), II, 128.

28 Ibid., 132.

${ }^{29}$ British Library, Add. MS. 18922, fo. 47.

${ }^{30}$ William Salt Library, Stafford, Salt Manuscripts, 481, 547.

31 J. Nichols, The History and Antiguities of the County of Leicester, 4 vols. (Leicester, 1804), III, part 2, Appendix IV, 39.

32 LRO D730 Barker Mss, vol IV, fols. 15,20.

${ }^{33}$ NAO, PR 1710, fo.40.

${ }^{34}$ S. Porter, 'The Fire Raid in the English Civil War', War and Society, II (1984).

${ }^{35}$ NAO, DDN 122. This state of affairs lasted into the next decade, with only slight and inconsistent recoveries.

${ }^{36}$ L. Hutchinson, Memoirs of the Life of Colonel Hutchintson (London, 1806), 262. 
${ }^{37}$ NAO, PR1710, fo. 49.

38 A.C. Wood, Nottingfamsfire in the Civil War (2nd edn., Wakefield, 1971), 120.

${ }^{39}$ Bennett, (ed.), A Nottingfamsfire Village xxvii.

40 Staunton Hall Family Papers, 34/16, Account Book of Lieutenant Gervase Hewit.

${ }^{41}$ Osborne, 'The People, the War', 99-100.

${ }^{42}$ R. Hutton, The Royalist War Effort (London, 1982), 148, 156.

${ }^{43}$ Derbyshire County Record Office, D258M/34/10, fols.3-5.

${ }^{44}$ Hutton, The Royalist War Effort 162-3.

${ }^{45}$ Bennett, 'The Royalist War Effort in the North Midands' 165-167. 